Winter 2011

\title{
A Review of Beyond Citizenship: American Identity After Globalization, by Peter J. Spiro
}

Andy Williams

Indiana University Maurer School of Law

Follow this and additional works at: https://www.repository.law.indiana.edu/ijgls

Part of the Constitutional Law Commons, Immigration Law Commons, and the International Law

\section{Commons}

\section{Recommended Citation}

Williams, Andy (2011) "A Review of Beyond Citizenship: American Identity After Globalization, by Peter J. Spiro," Indiana Journal of Global Legal Studies: Vol. 18 : Iss. 1 , Article 23.

Available at: https://www.repository.law.indiana.edu/ijgls/vol18/iss1/23

This Book Review is brought to you for free and open access by the Law School Journals at Digital Repository @ Maurer Law. It has been accepted for inclusion in Indiana Journal of Global Legal Studies by an authorized editor of Digital Repository @ Maurer Law. For more information, please contact rvaughan@indiana.edu.

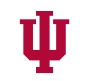

JEROME HALL LAW LIBRARY

INDIANA UNIVERSITY

Maurer School of Law
Bloomington 


\title{
A Review of Beyond Citizenship: American Identity After Globalization by Peter J. Spiro
}

\author{
ANDY WILLIAMS ${ }^{*}$
}

Professor Peter J. Spiro's ${ }^{1}$ book, Beyond Citizenship: American Identity After Globalization, ${ }^{2}$ examines the changing nature of citizenship, specifically U.S. ${ }^{3}$ citizenship, in the face of globalization. Spiro's analysis comes to some rather radical conclusions about the future significance of citizenship and the role of nations in international politics and everyday life. His main thesis is that the importance of U.S. citizenship is waning due to a breakdown in the traditional distinctions between U.S. citizens and the rest of the world. ${ }^{4}$ As the benefits conferred and duties required by U.S. citizenship become more diluted, Spiro asserts, citizenship and nationhood are increasingly anachronistic as signifiers of community in a global world..$^{5}$ In addition, Spiro critiques the way that law defines U.S. citizenship - whether with regard to birth or territorial presence-as inaccurate and arbitrary, contributing to the decline of citizenship as an important status. ${ }^{6}$

The enormously ambitious nature of Spiro's ultimate assertionthat nations will cease to be major organizational and political entities as a result of this decline-means that some of his arguments are difficult to accept and can, at times, seem hasty and conclusory. That said, his book is well reasoned and thought provoking, and many of his unique observations resonate strongly in today's changing society.

* Editorial Staff, Indiana Journal of Global Legal Studies; J.D. Candidate, 2011, Indiana University Maurer School of Law; B.A., 2008, DePauw University.

1. Peter J. Spiro holds the Charles R. Weiner Professorship in international law at Temple Law School.

2. Peter J. Spiro, Beyond Citizenship: American Identity AfTer Globalization (2008).

3. Spiro consistently uses the term "American," but this review will use the descriptor "U.S." for the sake of accuracy.

4. SPIRO, supra note 2 , at 6.

5. Id. at 5,6 .

6. Id. at $30,111$.

Indiana Journal of Global Legal Studies Vol. $18 \# 1$ (Winter 2011)

(C) Indiana University Maurer School of Law 
I have chosen three of Spiro's many interesting arguments for closer analysis in this review. ${ }^{7}$ First, I will examine Spiro's critique of U.S. citizenship law, both current and historic. Second, I will turn to Spiro's discussion of the benefits and duties attached to citizenship and their effect on citizenship as a desirable status. Finally, I will explore Spiro's suggestions for future replacements of citizenship and nationhood as the foundations of human community.

Spiro breaks his discussion of the legal status of citizenship into two parts: citizenship by birth $^{8}$ and citizenship through naturalization. ${ }^{9}$ Neither of these categories, according to Spiro, provides an accurate method for determining who is a part of the U.S. community and who is excluded.10 Citizenship by birth can be extended to someone born coincidentally to parents temporarily in the United States, who may never again return, and yet that person would remain a U.S. citizen. Moreover, a temporary resident with relatively few ties to the United States may naturalize as a citizen, while a lifelong U.S. resident may find it economically or legally impractical to do so. Spiro uses such examples of the inaccuracies of legal citizenship to support his claim that, as globalization makes travel and communication across national borders more convenient and commonplace and the U.S. community becomes more diverse and less exclusive, the importance of citizenship as a status is diminishing to a vanishing point. ${ }^{11}$

In his critique of the legal definition of U.S. citizenship, one of Spiro's main arguments is that much of what formerly set the United States apart from the rest of the world, including its culture and commitment to constitutional democracy, has become widespread due to globalization. ${ }^{12}$ This observation works two ways. First, it means that territorial presence, once an important factor in determining cultural and communal attachment, is much less useful in the face of globalization. ${ }^{13} \mathrm{~A}$ person born by chance in the United States might have less of a connection with traditional U.S. culture and political philosophy than a person born in Vancouver; yet U.S. law would recognize the person born in the United States as a citizen, and not the person born in Vancouver, based purely on territorial presence. Second,

7. A reader concerned with the many issues surrounding the phenomenon of globalization and its effects on American policies, which also include issues of dual citizenship and the consequences of September 11, 2001, for the rights of aliens, will be interested in reading Spiro's book in its entirety.

8. See SPIRo, supra note 2, at 9 (describing those "born American").

9. See id. at 33 (describing those "made American").

10. Id. at 33,56 .

11. Id. at 19,58 .

12. Id. at $44-47$.

13. Id. at 24-25. 
it means that as U.S. political ideals spread to more and more countries and are adopted by more and more people, the attributes that make the United States unique become increasingly commonplace. As Spiro observes, "[o]nce everyone is an American, no one is an American."14

To emphasize his point that American citizenship means less today than it used to, Spiro points to declines in the naturalization rate as a marker of "rational apathy" toward citizenship. ${ }^{15}$ By "rational apathy" Spiro means that there is little utility in becoming a citizen when the distinctions between U.S. citizens and the rest of the world are becoming fewer and fewer. Because his project is not to reform citizenship law, but rather to demonstrate that the importance of citizenship is diminishing, Spiro offers no suggestions for improvement. He simply takes it as further proof that his thesis is sound.

On one level, Spiro's critique of U.S. citizenship law and its methods for defining citizenship status is perfectly accurate. His examples and hypotheticals effectively support his case that the current system rests on arbitrary and archaic definitions of citizenship that can, when taken to the extreme, offer answers that defy logic. Why, indeed, should the children of tourists who have no intention of returning to the United States be considered lifelong citizens while hard-working undocumented laborers who pay their taxes are effectively barred from that same status? Spiro makes a convincing case that such unsatisfactory results have their roots in globalization and that the structure of citizenship law was created without regard for such processes. His observations would make an effective introduction to a proposal to amend U.S. citizenship law.

But that is not Spiro's goal. He hopes to demonstrate that the status of citizenship itself is becoming obsolete and, along with it, the role of nations as the primary organizational bodies in the global community. ${ }^{16}$ Because this view is somewhat unconventional, his argument that U.S. citizenship laws are flawed is unlikely to convince the average reader. For one thing, Spiro focuses exclusively on the uncommon scenarios in which the failures of citizenship law become obvious, while ignoring the vast majority of U.S. residents who do fall into the categories established by the current system. It is unreasonable to call into question the practicality of an entire system by presenting only the rare failures on the edges of the law's applicability.

Another serious flaw in Spiro's reasoning relates to his claim that "Io]nce everyone is an American, no one is an American." 17 This

14. Id. at 52 (emphasis in original).

15. Id. at 58 .

16. Id. at 4-6.

17. Id. at 52 . 
observation presupposes that the United State's only valuable asset is its uniqueness from the rest of the world, particularly with regard to its political philosophy. To begin with, Spiro greatly exaggerates the extent to which the rest of the world has embraced an "American" style of constitutional democracy. But even assuming arguendo that every country is on the verge of adopting such a form of government, it is hard to see how this would devalue U.S. citizenship. The value of the U.S. political experiment is not found in its status as an experiment, but rather in the substantive values that it represents, and these remain valuable even in a world where everyone has adopted them. It could be just as easily observed that once everyone is an American, everyone is an American. It does not follow that once the United States is no longer the sole refuge for those who desire representative constitutional democracy that citizenship as a status fails to meaningfully describe the U.S. community.

Another line of Spiro's argument centers on the benefits provided and the duties required of citizens. He begins by asserting that-jury duty aside--there are no real duties associated with citizenship. 18 Military service, no longer obligatory with the demise of the draft, is shared by citizens and non-citizens alike, and taxes are based on residence rather than citizenship. ${ }^{19}$ This revelation will probably not be that surprising to most readers, but Spiro goes on to argue that the benefits traditionally associated with citizenship are similarly inconsequential when compared to those held by non-citizens. ${ }^{20}$ Spiro points out that this has not always been the case, citing a long list of historical discrimination against non-citizens, from occupational requirements to property ownership restrictions. ${ }^{21}$ But as the United States has become more inclusive and discrimination of this kind has become increasingly disfavored, Spiro argues, the distinctions between citizens and non-citizens, in terms of benefits, have greatly decreased, to the point of being insufficient as incentives to seek citizenship. ${ }^{22}$

The first potential benefit Spiro addresses is "locational security," or the freedom to remain in U.S. territory without the threat of removal. ${ }^{23}$ This right, Spiro asserts, is not unique to citizens, but is afforded to citizens and legal aliens alike. ${ }^{24}$ Even illegal aliens are not as disadvantaged in this respect as is popularly believed, Spiro argues,
18. Id. at 82 .
19. Id.
20. See id. at 89-91.
21. Id. at 84 .
22. See id. at 91, 95-97.
23. Id. at 85-88.
24. Id. at 86 . 
because, as a practical matter, the government lacks sufficient resources to pursue and enforce the law against more than a small minority of aliens residing illegally in the United States. ${ }^{25} \mathrm{He}$ makes the point that "[o]ne can live in the United States as an 'illegal' alien with little fear, on a day-to-day basis, of removal."26 Spiro's point is that in terms of locational security, legal (or at least stable) residency, not citizenship, is the threshold at which practical rights attach.

Second, Spiro turns to federal benefits and their availability to noncitizens. In spite of a 1996 law that threatened to deprive many noncitizen aliens of federal welfare benefits, Spiro points out that many social benefits are still available, like food stamps and emergency medical care. ${ }^{27}$ Again, Spiro's point in this section is that while gaining legal residency may be essential in becoming eligible for certain benefits, legal residency is not citizenship. ${ }^{28}$ Citizenship as a status adds little, in this context, to the rights of the individual and is thus not an important distinction.

The third category of privilege that Spiro discusses is the right to participate in the political process. Here, at last, it seems that the distinction between citizens and non-citizens is perfectly clear-cut: citizens can vote and run for office, but aliens cannot. Spiro, however, offers a different point of view. He identifies two ways in which he believes non-citizens can participate meaningfully in the political world of the United States. First, virtually all aliens, and citizens, belong, on some level, to civil society organizations and interest groups. ${ }^{29}$ Second, "aliens enjoy powerful advocates in the form of their homeland governments." 30 According to Spiro, these two paths by which noncitizens can gain access to the political system serve to compensate for their disenfranchisement. ${ }^{31}$

Spiro's section on the benefits and duties attached to citizenship contains both his strongest and his weakest arguments. His overall point-that legal residency rather than citizenship is the meaningful status to which many benefits attach-is well taken and certainly is strong support for his central thesis regarding the weakening of citizenship and nationhood. It is true that the less one has to gain from becoming a citizen rather than simply obtaining legal residency, the less incentive there will be to take that step. One response to this line of

\footnotetext{
25. Id. at 88 .

26. Id.

27. Id. at 89-91.

28. Id. at 91 .

29. Id at 93-94.

30. Id. at 94 .

31. Id.
} 
reasoning is that it suggests a deficiency, not with the entire notion of citizenship, but rather with the way U.S. law allocates benefits to its citizens. Even so, Spiro's broader argument in this section is successful.

Some of Spiro's underlying assertions, however, are less strong. In the context of locational security, for instance, he seems to confuse objective freedom with freedom from fear. It may well be the case that inefficiencies in the U.S. immigration enforcement regime are such that the average undocumented alien has little chance of being apprehended and deported on any given day. But it is questionable whether this really means that undocumented aliens live "with little fear, on a dayto-day basis, of removal." 32 Removed from theory, practical security and freedom from fear of removal are not related in the ways that Spiro suggests. In addition, his observations regarding the political power of non-citizens are less than convincing. It is not clear that membership in a broad political block with many and varied political agendas, such as a racial or ethnic group, can serve as a satisfactory substitute for the opportunity to vote and hold public office. Such a substitute is obviously insufficient for someone whose views are not aligned with the majority position of the group. Neither is it the case that an alien's homeland government can fill this void as the powerful advocate Spiro envisions. In many cases, an alien's homeland government is not even powerful enough to control the social and political situations in its own country, let alone apply meaningful political pressure on the U.S. political system to protect the rights of its diaspora. In this way, Spiro's argument about the distinctions between citizenship and legal residence is weakened by the questionable logic of its underpinnings.

The final section of this review addresses Spiro's suggestions for a future in which citizenship and nationhood are no longer the primary signifiers of global community. Spiro suggests that other associations and relationships will serve as the centers of community and the forums for public issues in such a future. ${ }^{33}$ Religions, corporations, and even gated communities are among the organizations that Spiro anticipates could fill this void. ${ }^{34}$ The goal of Spiro's discussion is, in his own words, "to demonstrate that the state is not the only game in town. There is nothing categorically different about state regulations; the state is just another (albeit powerful) form of association." 35

Spiro sees a place for non-state organizations in just about every aspect of future public life, including security, redistribution of assets,

32. Id. at 88 .

33. Id. at $137,156-57$.

34. Id, at $141-42$.

35. Id. at 148 . 
and even everyday rights and responsibilities. ${ }^{36}$ Religions often place more onerous restrictions on behavior than any state-imposed laws. ${ }^{37}$ Private contractors are already employed in complex security arrangements, including deployment overseas. ${ }^{38}$ Insurance companies and other private associations, such as family networks, religions, corporations, or other non-state entities, emulate social welfare services. ${ }^{39}$ It seems that at least some part of the groundwork for Spiro's stateless and citizen-less future has already been laid.

At this point, the reader may begin to wonder what this discussion of privatization has to do with citizenship. Spiro's answer is that these private organizations and associations can do what U.S. citizenship no longer can: discriminate and exclude. ${ }^{40}$ Throughout his book, Spiro argues that to maintain a cohesive identity, citizenship must be able to "set the terms of admission and for expulsion." ${ }^{41}$ This is not to suggest that Spiro is advocating greater discrimination. His argument is simply that as U.S. citizenship becomes more inclusive, people will come to rely on private organizations to define community and identity. ${ }^{42}$

In his final discussion, the ambitious nature of Spiro's thesis becomes clear. Spiro observes that the framework for his vision of the future is already taking shape around us. However unlikely his portrait of a world in which decisions of governance and social order are completely divorced from the state, and citizenship is of less importance than membership in a private organization, its foundations are not completely implausible. Although not all of Spiro's arguments are convincing and some are seriously flawed, his thesis is thought provoking in a way that only an ambitious and controversial book can be. While it may not signal the death of citizenship and statehood as we know them, Spiro's book is worth reading for its unique perspectives on the effects of globalization and the changing nature of citizenship.

\footnotetext{
36. Id. at 138-44.

37. Id. at 141 .

38. Id. at 140 .

39. Id. at $144-48$.

40. Id. at $156-57$.

41. Id. at 156 .

42. Id. at 156-57.
} 
